\title{
MENGEMBANGKAN KREATIVITAS GURU PAUD DALAM MENULIS CERITA ANAK BERBASIS KARAKTER DI JAKARTA DAN SEKITARNYA
}

\author{
Eva Riza ${ }^{1}$, Muasisah Jadidah ${ }^{2}$,Putri Ratih Puspitasari ${ }^{3}$, Sisca Nurul Fadila, ${ }^{4}$ \\ Program Studi S1 PAUD Fakultas Keguruan dan Ilmu Pendidikan \\ Universitas Mohammad Husni Thamrin
}

Correspondence author: Evar Riza,e-mail: evafideza@gmail.com

DOI: https://doi.org/10.37012/jipmht.v4i2.445

\begin{abstract}
Abstrak
Berdasarkan hasil penelitian masih banyak permasalahan dalam penyelenggaran pendidikan Anak Usia Dini, salah satu permasalahan yang ada adalah metode yang digunakan dalam menyampaikan materi pembelajaran agar potensi anak dapat dikembangkan melalui berbagai aktivitas. Salah satu metode yang menyenangkan adalah menggunakan metode bercerita di dalam kelas. Metode bercerita merupakan salah satu metode yang digunakan guru untuk mengembangkan aspek perkembangan Nilai-Nilai Agama dan Moral (NAM). Belum semua guru mampu menggunakan media dan metode yang tepat untuk pembelajaran. Buku cerita dengan metode bercerita adalah sebagai sarana yang dapat diterapkan dalam pembelajaran. Keterbatasan buku cerita dan keterbatasan guru dalam menulis cerita masih rendah, belum memahami tata cara penulisan sesuai kaidah, cara menemukan ide atau gagasan cerita anak. Berdasarkkan hal tersebut, perlu dilakukan pelatihan bagi guru PAUD, melalui kegiatan PkM Prodi PAUD UMHT dengan mengadakan pelatihan menulis cerita bagi guru PAUD di lingkungan sekolah sekitar wilayah Jakarta. Kegiatan ini bertujuan mengembangkan kreativitas guru PAUD dalam menulis cerita anak berbasis karakter. Metode pelaksanaan program ini dengan pelatihan dan pendampingan secara virtual, yaitu pelatihan dengan memberikan pemahaman tentang sistematika penulisan cerita anak berbasis karakter serta guru dilatih menulis cerita anak. Pelatihan ini diberikan kepada 14 orang guru mulai bulan Agustus sampai dengan November 2020. Hasil pelatihan adalah terealisasinya 14 naskah cerita dengan nilai-nilai karakter yang telah dijadikan dalam satu buku dengan judul "Ontologi Cerita Anak Berbasis Karakter, Implementasi Penanaman Nilai-Nilai Pendidikan Karakter bagi Anak Usia Dini". Hasil pelatihan didapat feedback hasil postest sebagai berikut; $64,3 \%$ materi cerita sesuai dengan kebutuhan; $71,4 \%$ materi sangat mudah dipahami; $64,3 \%$ bimbingan membantu menemukan ide dan membuat naskah cerita;57.1\% waktu dalam membuat naskah cerita cukup; dan 85,7\% termotivasi untuk membuat naskah cerita anak selanjutnya.Kegiatan ini belum difokuskan pada aplikasi keterampilan penyampaian cerita di kelas dikarenakan adanya pandemik Covid-19, maka belum dapat diketahui sejauh mana hasil pelatihan ini berguna untuk mendukung peningkatan pembelajaran. Saran kegiatan pengabdian selanjutnya adalah melatih guru agar dapat mengaplikasikan di kelas dengan kegiatan pelatihan teknik bercerita guna mengetahui lebih lanjut keberhasilan pelatihan menulis cerita untuk guru PAUD.
\end{abstract}

Kata Kunci: kreativitas, guru PAUD, menulis cerita anak, karakter

\begin{abstract}
Based on the research findings that early childhood education still face many problems dealing with method of teaching, where it can enhance child potentials through any activities. Story telling is one of methods used by the teacher to develop moral and religion values.Not all teachers are able to use
\end{abstract}


suitable media and methods for teaching. Story book and story telling are medium can be implemented in teaching children. Unfortunately, story books are not available and most teachers are not competent in writing because of lacking knowledge on how to write nor having any idea to write story. That is why it is important for Early Childhood Education Department of Mohammad Husni Thamrim University to train early childhood teacher to write story for children through communities service program. The aim of the training is develop early childhood teacher creativities in writing character based story for children.The community services conducted for 14 teachers which is conducted through virtual and practical writing with mentorship from August through November 2020.The training produced 14 character based stories compiling in one book which is called the ontology of character based children stories, cultivating educational character values for early childhood. The training feedbacks are as follows: (1) 63.4 percent of the writing content appropriate to teachers' need, (2) 71.4 percent material are easy to understand, (3) 64.3 percent found that mentoring are helpful in finding ideas and writing. Moreover, 57.1 percent respondents says that its enough times to write a story, and furthermore 85.7 percent respondents are motivated to write their own stories.This program not yet applying telling stories in the classroom caused of pandemic covid-19, and surely it is not certain that the effect of the training toward improving learning. So it is suggested that to train teacher on how to apply story telling next community service program in order to know the effect of teacher's writing training.

Keywords: creativity, early childhood teacher, writing child story, character

\section{PENDAHULUAN}

Guru PAUD memiliki peranan yang penting untuk menciptakan kegiatan belajar seraya bermain yang sesuai dengan tahapan perkembangan anak. Peran guru dalam menstimulasi seluruh aspek perkembangan anak amatlah penting, salah satu aspek perkembangan anak usia dini yang perlu dioptimalkan yakni perkembangan bahasa. Pengenalan literasi sejak usia dini harus dimulai dari kegiatan mendengar cerita.

Guru PAUD harus memiliki kreativitas dalam menulis buku-buku cerita yang menarik bagi anak, karena buku cerita anak yang sudah ada belum tentu sesuai dengan kondisi dan lingkungan masing-masing satuan PAUD (TK). Pada kenyataannya, guru-guru PAUD masih belum terbiasa membuat suatu karya tulis khususnya menulis cerita bagi anak. Selain itu, masih banyak guru PAUD kurang memiliki ide cerita yang akan dituangkan ataupun belum memahami tata cara menulis cerita anak.

Berdasarkan hal tersebut di atas, maka guru-guru PAUD perlu dibekali pengetahuan dan pengalaman dalam menulis cerita yang menarik bagi anak-anak dan mengandung unsur moral untuk pembentukan karakter peserta didiknya dan disesuai dengan situasi dan kondisi di daerahnya masing-masing. Melalui cerita tersebut, akan memudahkan guruguru PAUD dalam menanamkan Pendidikan karakter bagi anak usia dini. 
Menurut Kamus Besar Bahasa Indonesia keterampilan adalah kecakapan seseorang untuk memakai bahasa dalam menulis, membaca, menyimak dan berbicara. Seseorang dapat menciptakan ide dan kreatifitasnya dalam mengerjakan sesuatu menjadi lebih bermakna dan menghasilkan sebuah nilai melalui sebuah keterampilan. Keterampilan harus dilatih dan dikembangkan secara optmal agar keahlian yang dimiliki dapat dikuasai dengan maksimal sehingga dapat bermanfaat bagi manusia.

Menulis adalah suatu proses menuangkan fikiran perasaan dan pengalaman seseorang untuk disampaiakan kepada orang lain dalam bahasa tertulis. (Fuad, 2012:67). Seorang penulis harus mampu memikirkan ide yang hendak disampaikan agar apa yang ditulis dapat bermanfaat bagi pembaca. Di dalam menulis dbutuhkan pengetahuan dan kemampuan dalam menentukan tanda baca, dan kemampuan dalam menggunakan huruf besar dan huruf kecil. (Jamaris, 2014 :155).

Cerita adalah karangan yang menceritakan suatu atau beberapa peristiwa dan bagaiamna peritiwa-peristiwa itu dapat berlangsung serta berisi tentang fakta yang benar-benar terjadi ataupun sesuatu yang kita khayalkan. Rangkaian kejadian ini disusun secara kronologis, dan dituangkan dalam bentuk bahasa tulis ataupun bahasa lisan. Di dalam sebuah karangan terdapat beberapa tokoh dan kejadian yang dapat membuat secuah cerita menarik untuk dibaca oleh pembaca. (Widhago, 1994 :106).

Cerita adalah rangkaian peristiwa yang disampaikan, baik berasal dari kejadian nyata (non fiksi) ataupun tidak nyata (fiksi). Manfaat cerita antara lain : "Bercerita untuk anak usia dini", http://www.anakku.net,html (akses 10 februari 2020), antara lain: (1) Membangun kedekatan sosial emosional antara pendidik dengan anak, (2) Media penyampaian pesan/ nilai moral karakter dan niali agama yang efektif, (3) Mengembangkan pola berfikir kritis dan imajinasi, (4) Menyalurakan dan mengembangkan emosi personal yang baik, (5) Membantu proses motoric halus peniruan perbuatan baik tokoh dalam cerita, (6) Memberikan dan memperkaya pengalaman batin, (7) Sarana hiburan dan penarik perhatian, (8) Menggugah minat baca, dan (9) Sarana membangun watak / karakter mulia. 
Bung Karno pernah mengatakan bahwa "Bangsa ini harus dibangun dengan mendahulukan kepentingan pembangunan karakter. Karena hal inilah yang membuat Indonesia menjadi bangsa yang besar, maju dan jaya, serta bermartabat. Jika character building ini tidak dilakukan, bangsa Indonesia akan menjadi bangsa kuli. Dalam undang-undang sisidiknas nomor 20 tahun 2003, Bab II pasal 3 berbunyi “ pendidikan nasional berfungsi mengembagkan kemampuan dan membentuk watak serta peradaban bangsa yang bermartabat dalam rangka mencerdaskan kehidupan bangsa.

Undang-Undang tersebut di atas memiliki tujuan untuk mengembangkan potensi peserta didik agar menjadi manusia yang beriman dan bertaqwa kepada tuhan yang Maha Esa, berakhlak mulia, sehat,, berilmu, cakap, kreatif, mandiri dan menjadi warga Negara yang demokratis serta bertanggung jawab". Narwan, "Tanamkan pendidikan karakter melalui dongeng", https:siedoo.com/berita-6159 (akses 10 februari 2020).

Dr. Sugiarti, M.Pd mengatakan bahwa, cerita anak dapat menjadi perantara yang sangat efektif untuk mendidik anak. Terlebih dimasa golden age, sehingga penulis tidak hanya menulis kreatif saja, akan tetapi juga melakukan penanaman nilai. Proses kreativitas harus dilakukan guru untuk mengolah imajinasi. Selain itu, kita juga harus menyisipkan hikmah-hikmah yang sebaiknya memang terkandung di buku cerita anak-anak. Kita mengemas nasihat dan pelajaran penting yang seharusnya didapat anak melalui kreativitas buku cerita anak. "ummaisyiyah bekali para guru menulis buku cerita untuk bangun karakter anak", http: //www.umm.ac.id.html (akses 10 februari 2020)

Dari hasil observasi di lembaga mitra, terlihat belum terlaksana secara keseluruhan kegiatan bercerita sesuai dengan nilai-nilai karakter. Hal ini dipengaruhi oleh faktor masih kurangnya wawasan dan kompetensi guru PAUD untuk menulis cerita anak yang memiliki konten penanaman nilai -nilai karakter yang sesuai dengan tahapan perkembangan anak dan sesuai dengan sistematika penulisan cerita yang baik dan benar.

\section{METODE PELAKSANAAN}


Desain yang dilaksankan dalam pelatihan ini adalah Project Based Learning, dimana guru dilibatkan dalam membuat proyek bersama yaitu menulis cerita anak yang disusun berdasarkan nilai-nilai karakter yang ditanamkan dalam cerita tersebut. Sedangkan untuk metode kegiatan dilakukan Blended Learning dengan membagi kegiatan menjadi dua jenis kegiatan utama, yaitu: 1). Workshop untuk memberikan pemahaman tentang sistematika penulisan cerita anak usia dini berbasis karakter pada guru PAUD, workshop penulisan kreatif secara on line dengan menggunakan aplikasi Google Class Room dan Zoom dan 2). sesi pendampingan menyusun buku cerita anak berbasis karakter yang dilakukan oleh guru-guru sekolah mitra yang dilakukan secara daring melalui email dan whatsapp untuk memfasilitasi peserta.

Peserta mengirimkan dan mengkonsultasikan draf cerita mereka pada tim fasilitator pengabdian, yang kemudian mendapatkan umpan balik untuk revisi. Ketercapaian proyek akan diukur menggunakan penilaian dengan menentukan dengan empat aspek penilaian yaitu knowing, reasoning, feeling, acting. Aspek ini merupakan karakter yang dikembangkan melalui pengetahuan (knowing) tentang moral, moral feeling atau penguatan emosi, pelaksanaan (acting) yaitu perbuatan bermoral hal ini diperlukan agar peserta didik atau warga sekolah lain yang terlibat dapat memahami, merasakan, menghayati dan mengamalkan nilai-nilai kebaikan (moral). Moral feeling merupakan penguatan aspek emosi peserta didik untuk menjadi manusia berkarakter. Aspek reasoning adalah memberikan penalaran dapat berfikir logis dan sistematis

\section{HASIL DAN PEMBAHASAN}

Guna menjawab permasalahan yang muncul, tim $\mathrm{PkM}$ menyusun beberapa kegiatan sebagai solusi, yaitu:1) Guru perlu diberikan pelatihan memberikan pemahaman tentang sistematika penulisan cerita anak usia dini berbasis karakter pada guru PAUD;2). Guru dilatih menulis cerita anak, karena dengan menulis sendiri cerita anak, pengetahuan yang didapat akan teraplikasikan secara nyata.

Kegiatan ini memberikan dampak yang cukup signifikan bagi guru PAUD, sehingga guru menguasai teknik menulis cerita dan memahami pentingnya literasi. Hal ini dapat dilihat dari penilaian hasil evaluasi peserta. Ketuntasan hasil kegiatan menulis cerita 
anak mencatat seluruh peserta berhasil menyelesaikan dengan baik. Aspek penilain dengan indikator tersebut terdiri dari;1) Knowing;2) Reasoning;3) Feeling;4) Acting. Seluruh peserta berhasil menyelesaikan pembuatan cerita anak dengan nilai-nilai karakter dan skor rata-rata yang didapat oleh semua peserta adalah $87.5 \%$.

Hasil kegiatan PkM melalui feedback melalui hasil post test dari 14 peserta 64,3\% menyatakan materi yang diberikan sangat sesuai dengan kebutuhan peserta, 71, $4 \%$ menyatakan materi yang diberikan sangat mudah dipahami oleh peserta, 64,3\% bimbingan yang diberikan oleh tim pelaksana sangat membantu peserta dalam menemukan ide dan membuat naskah cerita berbasis karakter. Selanjutnya 57.1\% menyatakan waktu dalam membuat naskah cerita cukup 5,7 \% menyatakan ya, ke depan nya termotivasi untuk membuat naskah cerita anak. Dengan demikian dapat disimpulkan bahwa pelatihan menulis cerita berdampak positif terhadap peserta pelatihan.

Dengan demikian, diharapkan implementasi penulisan cerita akan terwujud melalui tindakan. Guru menulis cerita, kemudian dibukukan, menjadi salah satu solusi untuk menghadapi kendala ketersediaan buku cerita anak dengan nilai-nilai karakter. Kelebihan lain dari guru menulis cerita adalah guru dapat menyesuaikan muatan cerita yang berprinsip pada pendidikan karakter secara otentik sesuai dengan kebutuhan pendidikan anak.

Sehubungan dengan adanya pandemik COVID-19, maka seluruh kegiatan dilaksanakan secara daring baik melalui aplikasi google class room, zoom maupun whatsApp. Diskusi baik antar tim maupun dengan peserta dilakukan melalui whatsApp group yang telah dibuat. Kegiatan pelatihan dimulai pada tanggal 15 Agustus 2020.

Kegiatan ini memuat beberapa materi yakni;1).Perkembangan Bahasa Anak Usia Dini, materi membahas mengenai penanaman nilai karakter pada sebuah cerita;2)Perkembangan Bahasa Anak Usia Dini, pada bagian ini dijelaskan tentang memahami bahasa berdasarkan konsep pengetahuan dan pengalaman yang sudah dimiliki sebelumnya;3)Media Penulisan Cerita, berisi tentang penerapan media yang tepat akan membantu mengatasi kesulitan dalam menuangkan ide/gagasan dalam 
menulis cerita anak;4)Langkah-langkah menulis cerita anak, pada topik ini dibahas tentang hal-hal yang harus dilakukan jika ingin jadi penulis, berisi dasar-dasar menulis cerita anak, langkah umum menulis cerita. Pada sesi ini tim pengabdian masyarakat sebagi narasumber dengan memberikan materi penulis cerita anak serta memberikan umpan balik terhadap draf tulisan peserta.

Kegiatan kedua dilakukan secara daring dengan membentuk group whatsapp, cara ini dipilih berdasarkan pertimbangan efektivitas serta kemudahan media sosial tersebut untuk dipakai sebagai wadah berdiskusi secara on-line. Kegiatan kedua menghasilkan empat belas (14) cerita anak dengan nilai-nilai karakter yang terdiri atas percaya diri, kejujuran dan tanggung jawab. Keempatbelas cerita tersebut berjudul;1) Aku Istimewa;2) Mari Berlatih;3) Menjadi Pemenang;4) Pensil Warna ;5) Putri Manggalika;6) Rani dan Lolipop;7) Jujur Itu Hebat;8) Hadiah Kejujuran;9) Anak Yang Bertanggungjawab;10) Krayon;11) Anak yang Jujur;12) Anak yang Rajin;13) Daur Ulang;14) Bimo dan Dudu.

Empat belas cerita yang dihasilkan guru PAUD berdasarkan nilai-nilai karakter yang akan mengajarkan pada siswa tentang nilai- nilai baik yang dapat diaplikasikan dalam kehidupan sehari-hari. Kegiatan pendampingan mencatat beberapa permasalah utama yang dihadapi mitra ketika menulis kreatif sastra anak.

Catatan permasalahan yang didapat dari kegiatan, yaitu masalah terkait kebahasaan, alur cerita dan masalah terkait tema. Masalah kebahasaan ditemukan berupa kesalahan tanda baca, ejaan dan koherensi antar kalimat, sedangkan persoalan terkait alur cerita yang ditemui adalah logika cerita dan alur cerita yang kurang berkembang. Selanjutnya, permasalahan tentang unsur tema berdasarkan penilaian peserta telah memahami dan memasukan tema nilai-nilai karakter dalam cerita yang mereka buat.

\section{SIMPULAN}

Kegiatan pengabdian kepada masyarakat ini mampu meningkatkan pemahaman guru akan pentingnya literasi dan berhasil melatih guru untuk menulis cerita anak dengan nilai-nilai karakter. Kegiatan ini berfokus pada guru PAUD sebagai fasilitator dalam proses belajar mengajar di kelas. kegiatan ini diharapkan guru dapat mengintegrasikan 
pengetahuan tersebut di dalam kurikulum melalui kegiatan pembiasaan harian anak di kelas yang tercantum di dalam Rencana Pelaksanaan Pembelajaran Harian.

Hasil pelatihan didapat feedback hasil postest sebagai berikut; 64,3\% materi cerita sesuai dengan kebutuhan;71,4\% materi sangat mudah dipahami;64,3\% bimbingan membantu menemukan ide dan membuat naskah cerita;57.1\% waktu dalam membuat naskah cerita cukup; dan $85,7 \%$ termotivasi untuk membuat naskah cerita anak selanjutnya. Berdasarkan hasil feedback dari peserta tersebut, skor terbesar pada peserta termotivasi untuk membuat naskah cerita anak selanjutnya dengan porsentase $85,7 \%$, artinya setelah mengikuti pelatihan ini, peserta termotivasi untuk menulis cerita anak. Skor terendah pada aspek waktu dalam membuat naskah cerita cukup dengan porsentase $57.1 \%$, artinya peserta membutuhkan waktu dalam mempelajarai penulisan yang terkait cerita anak.

Mengingat situasi pada pelaksanaan PkM pada masa Pandemi Covid-19, maka kegiatan ini belum difokuskan pada aplikasi keterampilan menulis cerita secara tatap muka di kelas, sehingga belum dapat diketahui sejauh mana pengetahuan literasi dan keterampilan menulis kreatif guru berguna untuk mendukung peningkatan literasi siswa yang diajar oleh guru-guru tersebut. Kekurangan ini dapat menjadi topik penelitian ataupun kegiatan pengabdian selanjutnya, guna mengetahui lebih lanjut keberhasilan pelatihan literasi menulis cerita untuk guru PAUD.

Berdasarkan kesimpulan dari pelaksanaan kegiatan pelatihan, maka dapat direkomendasikan untuk kegiatan PkM berikutnya adalah sebagai berikut:

1. Bagi Program Studi S1 PAUD:

Hasil kegiatan PkM ini dapat dijadikan sebagai ide pengembangan mata kuliah dan pemberian materi secara khusus dalam perkuliahan.

\section{Bagi Dosen/Tim PkM}

a. Pada kegiatan PkM Dosen selanjutnya dapat dikembangkan dengan materi Pelatihan Teknik Bercerita bagi Guru PAUD.

b. Pelaksanaan kegiatan pelatihan hendaknya memperhatikan waktu yang cukup yang diberikan bagi peserta dalam mengerjakan tugas dan Latihan. 
c. Tim PkM dapat bersinergi dengan organisasi profesi guru PAUD seperti IGTKI, IGRA, dan HIMPAUDI untuk rekrutmen peserta pelatihan.

d. Tim PkM dapat melakukan evaluasi pasca pelatihan dengan melakukan pemantauan melihat dampak pasca pelatihan terhadap peserta dan Lembaga asal masing-masing peserta.

\section{REFERENSI}

"Ummaisyiyah Bekali para Guru Menulis Buku Cerita untuk Bangun Karakter Anak", http: //www.umm.ac.id.html (akses 10 februari 2020).

Narwan, "Tanamkan Pendidikan Karakter melalui Dongeng", https:siedoo.com/berita6159 (akses 10 februari 2020).

"Bercerita untuk Anak Usia Dini", http://www.anakku.net,html (akses 10 februari 2020).

Dongeng untuk Anak. Sanggar Dongeng Ardika. Ngestiharjo, Kasihan, bantul. 2006

Teknik Mendongeng untuk Anak, Kak Kusumo Priyono, Gramedia Press, 2007

Bahasa Indonesia Pengantar kemahiran Berbahasa di Perguruan Tinggi, Djoko Widagho, Jakarta ; PT Raja Grafindo, 1994 
Kesulitan Belajar Perspektif, Assesmen dan Penanggulangannya, Martini Jamaris, Jakarta: Ghalia Indonesia, 2014.

Peraturan Menteri Pendidikan dan Kebudayaan Nomor 137 Tahun 2014 tentang Standar PAUD, Kementerian Pendidikan dan Kebudayaan, Jakarta: 2017.

Teori dan Praktek Penelitian Tindakan Kelas, Jauhar Fuad Tulung Agung; STAIN Tulungagung 2012. 